\title{
Individual variation in movements of satellite- tracked humpback whales Megaptera novaeangliae in the eastern Aleutian Islands and Bering Sea
}

\author{
Amy S. Kennedy ${ }^{1, *}$, Alexandre N. Zerbini ${ }^{1,2}$, Brenda K. Rone ${ }^{1}$, Phillip J. Clapham ${ }^{1}$ \\ ${ }^{1}$ National Marine Mammal Laboratory, Alaska Fisheries Science Center, NOAA, 7600 Sand Point Way NE, Seattle, \\ Washington 98115, USA \\ ${ }^{2}$ Cascadia Research Collective, 28 1/2 W. 4th Ave., Olympia, Washington 98501, USA
}

\begin{abstract}
Humpback whales utilize waters off the Aleutian Islands and Bering Sea as foraging grounds during summer months. Currently, the fine-scale movements of humpback whales within these feeding grounds are poorly understood. In the summers of 2007 to 2011, 8 humpback whales were tracked with satellite tags deployed near Unalaska Bay. Individuals were tracked for an average of $28 \mathrm{~d}$ (range $=8-67 \mathrm{~d}$ ). Three whales remained within $50 \mathrm{~km}$ of their tagging locations for approximately $14 \mathrm{~d}$, while 2 others explored areas near the northern shore of Unalaska Bay and Unimak Pass. Two whales moved west: one traveled to the Island of Four Mountains and returned to the northern side of Umnak Island, while the other moved through Umnak Pass and explored feeding areas on both sides of Umnak Island. Remarkably, 1 individual left Unalaska Bay soon after tagging and moved $\sim 1500 \mathrm{~km}$ (in $12 \mathrm{~d}$ ) along the outer Bering Sea shelf to the southern Chukotka Peninsula, Russia, then east across the Bering Sea basin to Navarin Canyon, where it remained until transmissions ceased. Most area-restricted search (i.e. foraging) was limited to waters shallower than $1000 \mathrm{~m}$, while movement into deeper water was often associated with travel behavior. Tagged animals spent more time on the Bering Sea shelf and slope than the North Pacific. Movement patterns show individual variation, but are likely influenced by seasonal productivity. This study provides evidence that although humpbacks aggregate in well-known foraging areas, individuals may perform remarkably long trips during the feeding season.
\end{abstract}

KEY WORDS: Humpback whale $\cdot$ Satellite telemetry $\cdot$ Aleutian Islands $\cdot$ Feeding ground $\cdot$ Movements

\section{INTRODUCTION}

The humpback whale Megaptera novaeangliae is a globally distributed, highly mobile species that typically undertakes long annual migrations between energy-rich, high-latitude summer feeding grounds and low-latitude winter breeding and calving grounds (Dawbin 1966, Clapham \& Mead 1999). While humpbacks are arguably one of the most wellstudied large whales in the world, habitat use and within-season movements are poorly understood range-wide, particularly in remote, offshore regions such as the Bering Sea. Most of our existing knowledge of North Pacific humpback whale distribution is the result of historical whaling data analysis together with modern photo-identification, genetic markrecapture (Baker 1985, Darling \& McSweeney 1985, Perry et al. 1990, Baker et al. 1998, Calambokidis et al. 2001) and line-transect studies (Moore et al. 2002, Zerbini et al. 2006a). A large-scale, oceanbasin-wide mark-recapture study, called Structure of Populations, Levels of Abundance and Status of Humpback Whales (SPLASH), was conducted between 2004 and 2006 and provides the most com- 
prehensive data regarding the status of North Pacific humpback whales today (Calambokidis et al. 2008, Barlow et al. 2011); however, SPLASH and similar studies yield only coarse-scale distribution and abundance information and are limited by low spatial and temporal effort. Here we present the first fine-scale humpback whale telemetry data collected from the eastern Aleutian Islands and Bering Sea feeding grounds.

Since predation by killer whales Orcinus orca on humpback whales in high-latitude feeding areas is rare (Dolphin 1987, Mehta et al. 2007), the latter's distribution in the North Pacific is almost certainly driven by prey abundance. Humpbacks feed on discrete, variable patches of small fish or eupausiids (Nemoto 1957, 1962, Krieger \& Wing 1984) in a nearly continuous arc from Russia to the western coast of the USA, within 5 loosely defined feeding areas: California and Oregon, Northern Washington and British Columbia, Southeast Alaska, Northern Gulf of Alaska, Aleutian Islands/Bering Sea, and waters off the Russian mainland and Commander Islands (Calambokidis et al. 2001, Fleming \& Jackson 2011). Humpback distribution in the eastern Aleutian Islands/Bering Sea feeding grounds is thought to be related to proximity of the nearest passes, which are dominated by strong tidal currents and mixing (Reed \& Stabeno 1994, Byrd et al. 2005, Sinclair et al. 2005). Eddies and fronts generated by water circulating through these passes create reliable prey aggregations between Unimak and Samalga Passes each year (Coyle 2005, Ladd et al. 2005a,b).

As in other well-studied humpback populations (Katona \& Beard 1990, Baker et al. 1990, Clapham et al. 1993), maternally directed site fidelity is a key factor driving North Pacific feeding area selection (Baker 1985, Darling \& McSweeney 1985, Waite et al. 1999, Calambokidis et al. 1996, 2008, Witteveen et al. 2009, Riley 2010). A number of photo-identification and genetic mark-recapture studies have described some interchange between eastern Aleutian Islands humpbacks and Kodiak (Alaska) whales, but there is little documented interchange between the Aleutians and more southerly feeding stocks (Darling \& McSweeney 1985, Baker 1985, Baker et al. 1987, Calambokidis et al. 1996, 2008, Waite et al. 1999, Riley 2010). Due to low humpback survey effort throughout most of the Bering Sea (particularly offshore), there is insufficient data to say whether eastern Aleutian Island humpbacks can be considered a discrete feeding aggregation from the rest of the Bering Sea. However, scant existing data (Omura \&
Ohsumi 1964, present study) suggests that eastern Aleutian Island humpbacks also visit unstudied areas throughout the Bering Sea. The scope of this longdistance, within-season movement variation is currently unknown.

In the past decade, satellite telemetry studies have consistently yielded fine-scale individual movement data that cannot be obtained, or even predicted, through other methods (e.g. Mate et al. 1998, 2007, Heide-Jørgensen et al. 2006, Horton et al. 2011, Zerbini et al. 2011). For this descriptive study, we use data from satellite tags attached to humpback whales off Unalaska Island (in the eastern Aleutian Islands) during the summers of 2007 to 2011 to describe their fine-scale movement and foraging patterns in a North Pacific humpback whale feeding ground.

\section{MATERIALS AND METHODS}

\section{Study area}

The eastern Aleutian Island region lies between Samalga Pass and Unimak Pass (between 54 $20^{\prime} \mathrm{N}$, $164^{\circ} 55^{\prime} \mathrm{W}$ and $53^{\circ} 46^{\prime} \mathrm{N}, 169^{\circ} 15^{\prime} \mathrm{W}$ ) to the west of mainland Alaska (Fig. 1). Unimak Pass is the first major pass encountered by the westward-flowing Alaska Coastal Current (Royer et al. 1979, Ladd et al. 2005a) and is dominated by high water flow and mixing. The resulting water property fronts, together with current, bathymetry, depth and slope, structure the nearby ecosystem to consistently concentrate prey in coastal waters of the eastern Aleutian Islands (Ladd et al. 2005a,b). Aside from the relatively high density of humpbacks in that area, Unalaska Bay was the tagging site during all 5 summers of the study because of its protected waters and proximity to Dutch Harbor (Alaska).

\section{Satellite telemetry and tagging}

Nine whales were tagged with the deep implantable configuration of the SPOT5 transmitter (Wildlife Computers), and 1 whale (2009) was tagged with a low impact minimally percutaneous externalelectronic transmitter (LIMPET) tag (Andrews et al. 2008, Schorr et al. 2009). Deep implantable tags were attached to the blubber and fascia/muscle layer of the whale's body using a fiberglass pole (Heide-Jørgensen et al. 2003, Zerbini et al. 2006b) and/or a custom-modified pneumatic line thrower 


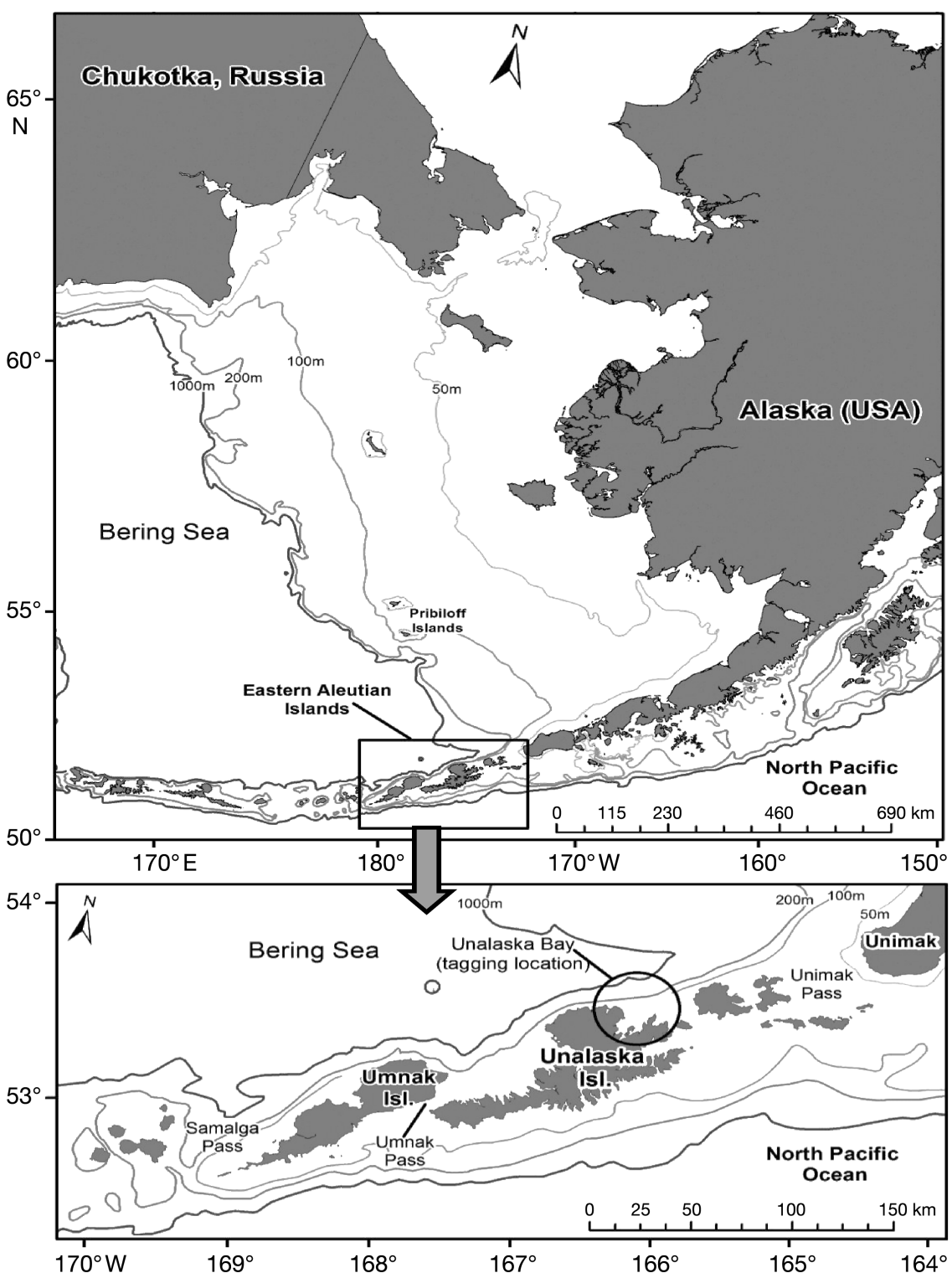

Fig. 1. Location of eastern Aleutian Islands and Bering Sea study area

filtering method. The Argos Filter (Freitas 2010) was then applied to all Argos observed locations in the software R (R Development Core Team 2011) in order to remove locations that implied extreme, unlikely deviations from the track's path.

\section{Switching state-space model}

A Bayesian switching state-space model (SSSM) (Jonsen et al. 2007) was applied to all Argos filtered data to estimate a position every $12 \mathrm{~h}$. The SSSM uses a first-difference correlated random walk (DCRW) model (Jonsen et al. 2005) to simulate the whale's movement process and assumes a correlated random walk on the differences between locations. The model was fit using $\mathrm{R}$ and WinBUGS software (Lunn et al. 2000, Spiegelhalter et al. 2003). Two chains were run in parallel, producing a total of 40000 Markov chain Monte Carlo (MCMC) samples each. The first 20000 samples were discarded as burn-in, and 1 out of every 20 remaining samples was retained (in order to reduce autocorrelation), for a total of 1000 samples to form the posterior distribution of model parameter estimates.

In order to quantify discrete behavioral modes, the DCRW model we used incorporated an index

(Air Rocket Transmitter System; Heide-Jørgensen et al. 2001). The LIMPET tag was deployed using a compound crossbow. Tags were duty-cycled to transmit every day for $6 \mathrm{~h}$ during daytime and $6 \mathrm{~h}$ during nighttime for the first 3 mo of transmission. After the first $3 \mathrm{mo}$, the transmitters were programmed to transmit every other day, following the same duty cycle, to conserve the battery life of the tag. Satellite tags were monitored by Argos Data Collection and Location Service receivers on NOAA TIROS-N weather satellites (Argos 1990), and locations were calculated by Argos, from Doppler-shift data when multiple messages were received during a satellite's passage overhead, using the standard least-squares based on mean turning angle and speed/direction autocorrelation parameters. Behavioral modes are estimated from the means of the MCMC samples within the model, producing continuous variables between 1 and 2; higher values represent higher turning angle and speed/direction variability. Modes are then classified (conservatively) as follows: behavioral mode 1 (1-1.25) assumes a low turning angle and speed/direction variability and is classified as transit behavior, and behavioral mode 2 (1.75-2) corresponds to higher turning angles and speed/direction variability, and is classified as area-restricted search (ARS). Unclassified behavior mode values fall between 1.25 and 1.75. 
While it is impossible, without real-time confirmation, to be certain that all ARS classifications are indicative of active foraging, the slower speed and higher turning angles observed during ARS generally correspond to foraging behavior in marine predators (Kareiva \& Odell 1987, Mayo \& Marx 1990). Therefore, for the sake of this discussion, ARS will be referred to hereafter as 'foraging'.

\section{RESULTS}

A total of 10 tags were deployed on humpback whales in August and September of 2007 through 2011 in Unalaska Bay, Alaska (Fig. 1). Judged by their size and behavior, all tagged whales were identified as adults, and no tagged whales were associated with a calf. One tag transmitted intermittently for only $3 \mathrm{~d}$ and is not considered further in this study. Another tag was deployed but did not transmit, for unknown reasons. The remaining 8 tags transmitted for an average of $28 \mathrm{~d}$ (range $=8-67 \mathrm{~d}$ ). All whales exhibited differing speed, direction and overall distance traveled within and between years (Table 1, Fig. 2). Whales traveled a minimum average of $46.0 \mathrm{~km} \mathrm{~d}^{-1}$ (range $=31.1-109.6 \mathrm{~km} \mathrm{~d}^{-1}$ ), and spent a significant portion of their time foraging (Table 1). All but one whale (Whale $\mathrm{G}$ ) remained relatively close to the tagging location for the period they were monitored (Fig. 2). Tagged whales visited habitats on the Bering Sea (north) side of the Aleutian Islands more often than the North Pacific (south) side, yet 2 whales traveled through Umnak Pass and spent brief periods foraging in the North Pacific. The tagged animals largely remained over shelf and slope habitat (1000 m or shallower) (Figs. $2 \& 3$ ).

In 2007, Whale A made a trip west to the Island of Four Mountains and returned to the northern side of Umnak Island over a period of $28 \mathrm{~d}$. This animal spent $98 \%$ of its time foraging. The other whale tagged on the same day in 2007 (Whale B) explored presumed feeding areas to the east of the tagging location, crossing Unalaska Bay and Unimak Pass before transmissions ceased (Fig. 2). In 2008, Whale C traveled nearly 3 times farther than the other whale tagged on the same date (Whale D). After tag deployment, Whale C traveled east to Unimak Pass, then west to Unalaska Bay for several days, then farther southwest to the Pacific side of Umnak Pass (Fig. 2). This animal spent $68 \%$ of its time foraging. Whale $\mathrm{D}$, however, remained within $50 \mathrm{~km}$ of Unalaska Bay for the duration of the tag transmissions, spending $99 \%$ of the time foraging. The single whale tagged in 2009 (Whale E; Fig. 2) remained within Unalaska Bay during the $7 \mathrm{~d}$ of tag transmission, with $85 \%$ of its time spent foraging. The animal tracked in 2011

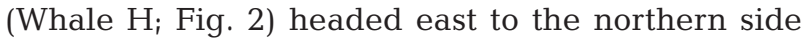
of Akutan Island and then across Unimak Pass. It remained largely near shore during tag transmission and spent $75 \%$ of its time foraging.

The 2 whales tagged in 2010 showed the most marked variation in movement observed throughout the study. Whale F (Fig. 2) traveled from Unalaska Bay west to northeastern Umnak Island, then southeast through Umnak Pass, presumably to forage on the Pacific side of the island, spending $56 \%$ of its time foraging. The other animal tagged that

Table 1. Summary of satellite telemetry and switching state-space model (SSSM) results from humpback whales tagged in Unalaska Bay from 2007 to 2011. Minimum distances represent the sum of distances between positions estimated every $12 \mathrm{~h}$. Average locations per day: number of good locations (of qualities 0, 1, 2, 3, A and B that passed the applied Argos Filter; Freitas 2010) used to generate the SSSM results. ARS: area-restricted search, considered foraging for the purpose of this study; PTT: Platform transmitter terminal_year

\begin{tabular}{|c|c|c|c|c|c|c|c|c|c|}
\hline \multirow{2}{*}{$\begin{array}{l}\text { Whale } \\
\text { ID }\end{array}$} & \multirow{2}{*}{ PTT no. } & \multirow{2}{*}{$\begin{array}{c}\text { Date } \\
\text { deployed } \\
\text { (dd.mm.уууу) }\end{array}$} & \multirow{2}{*}{$\begin{array}{l}\text { Tag } \\
\text { longevity } \\
\text { (d) }\end{array}$} & \multirow{2}{*}{$\begin{array}{c}\text { Minimum } \\
\text { total distance } \\
(\mathrm{km})\end{array}$} & \multirow{2}{*}{$\begin{array}{l}\text { Minimum } \\
\text { daily distance } \\
\qquad\left(\mathrm{km} \mathrm{d}^{-1}\right)\end{array}$} & \multirow{2}{*}{$\begin{array}{l}\text { Average } \\
\text { locations } \\
\text { per day }\end{array}$} & \multicolumn{3}{|c|}{ - Behavioral mode } \\
\hline & & & & & & & $\begin{array}{c}\text { Travel } \\
(\%)\end{array}$ & $\begin{array}{l}\text { ARS } \\
(\%)\end{array}$ & $\begin{array}{c}\text { Unclassified } \\
(\%)\end{array}$ \\
\hline A & 21809_07 & 11.08 .2007 & 28 & 1160 & 41.4 & 3.6 & 0 & 98 & 2 \\
\hline B & 21810_07 & 11.08 .2007 & 17 & 879 & 51.7 & 7.9 & 15 & 9 & 76 \\
\hline $\mathrm{C}$ & 21810_08 & 26.08 .2008 & 67 & 2341 & 34.9 & 5.7 & 2 & 68 & 30 \\
\hline $\mathrm{D}$ & 21809_08 & 26.08 .2008 & 36 & 813 & 22.6 & 6.6 & 0 & 99 & 1 \\
\hline $\mathrm{E}$ & 87769_09 & 05.08 .2009 & 8 & 249 & 31.1 & 5.9 & 0 & 85 & 15 \\
\hline F & 88720_10 & 01.08 .2010 & 15 & 589 & 39.3 & 8.9 & 3 & 56 & 41 \\
\hline G & 88721_10 & 01.08 .2010 & 26 & 2849 & 109.6 & 6.2 & 85 & 8 & 7 \\
\hline $\mathrm{H}$ & 87771_11 & 10.09.2011 & 29 & 1082 & 37.3 & 2.8 & 0 & 75 & 25 \\
\hline & Mean (SD) & & $28.3(18)$ & $1245.3(890.5)$ & $46(27)$ & $5.9(2)$ & $13.1(29.5)$ & $62.3(36.2)$ & $24.6(25.1)$ \\
\hline
\end{tabular}



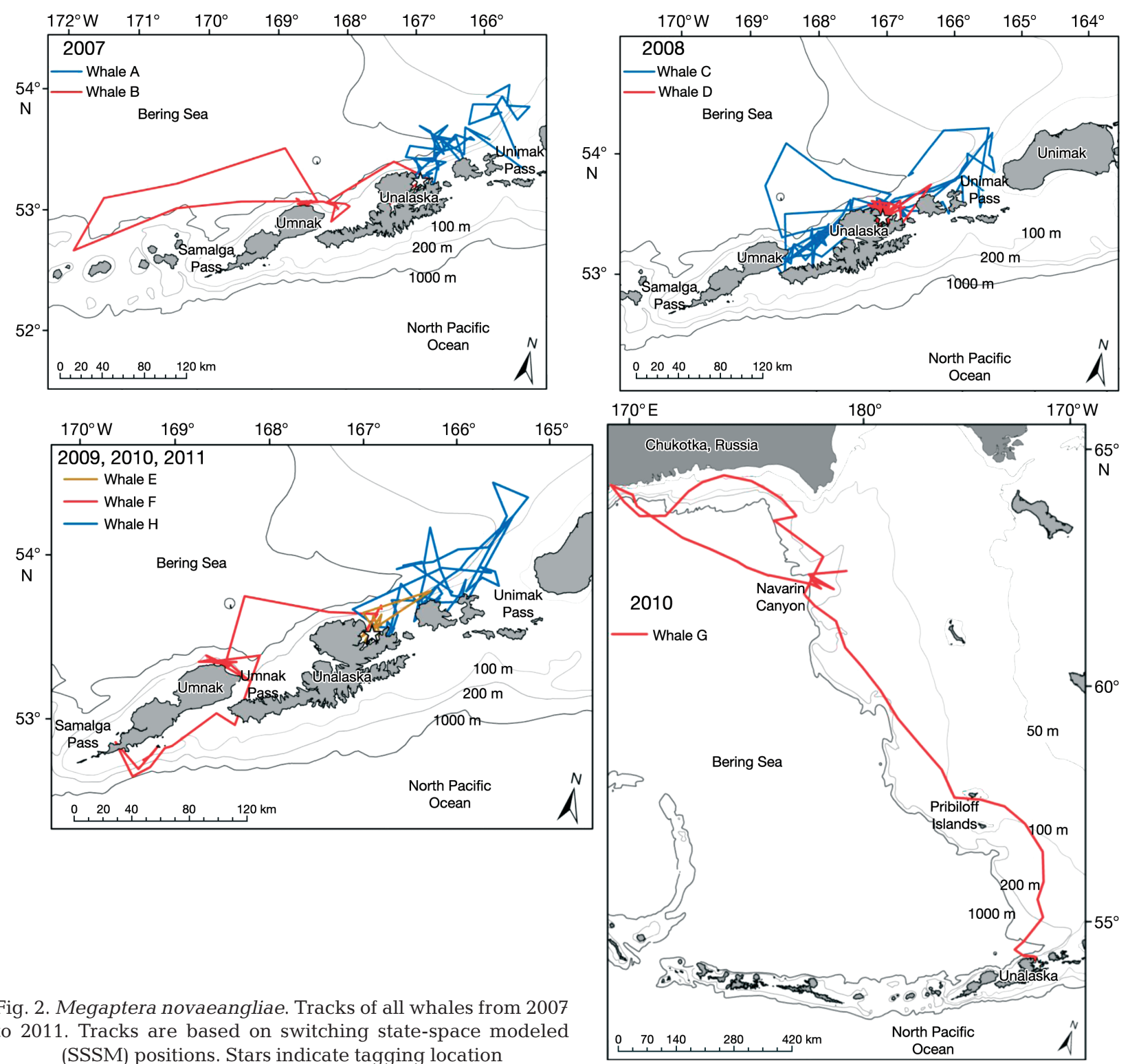

Fig. 2. Megaptera novaeangliae. Tracks of all whales from 2007 to 2011. Tracks are based on switching state-space modeled (SSSM) positions. Stars indicate tagging location

year (Whale G; Fig. 2) left Unalaska Bay 3 d after tagging and, over a period of $16 \mathrm{~d}$, traveled at least $1500 \mathrm{~km}$ northwest along the outer Bering Sea shelf to the southern Chukotka Peninsula, Russia. After reaching the northern extent of Vityaz Valley on 14 August, the animal headed west along the shelf break (Fig. 2). Over the next several days, Whale G moved east across the Bering Sea basin before turning southeast. Whale $\mathrm{G}$ stopped in Navarin Canyon $\left(60^{\circ} 30 \mathrm{~N}, 179^{\circ} 20 \mathrm{~W}\right)$, where it remained until transmissions ceased $2 \mathrm{~d}$ later on 26 August. Whale G spent $85 \%$ of its time travelling. The long-range movement of this individual, encompassing nearly $3000 \mathrm{~km}$ in $26 \mathrm{~d}$, equates to an average travel rate of $110 \mathrm{~km} \mathrm{~d}^{-1}$.

\section{DISCUSSION}

Telemetry data from this study largely support the findings of historical and current studies (Moore et al. 2002, Zerbini et al. 2006a, Calambokidis et al. 2008, Riley 2010) that have shown that humpback whales congregate in the shallow, highly productive coastal waters north of the eastern Aleutian Islands, between Unimak and Samalga Passes (Fig. 1). The extremely high proportion of foraging (Table 1) within the narrow band $200 \mathrm{~km}$ east and west of Unalaska Bay further emphasizes the importance of the waters off the eastern Aleutian Islands for humpback whales (Figs. 3 \& 4). However, the spatial and temporal movement variation evident in these telemetry data 


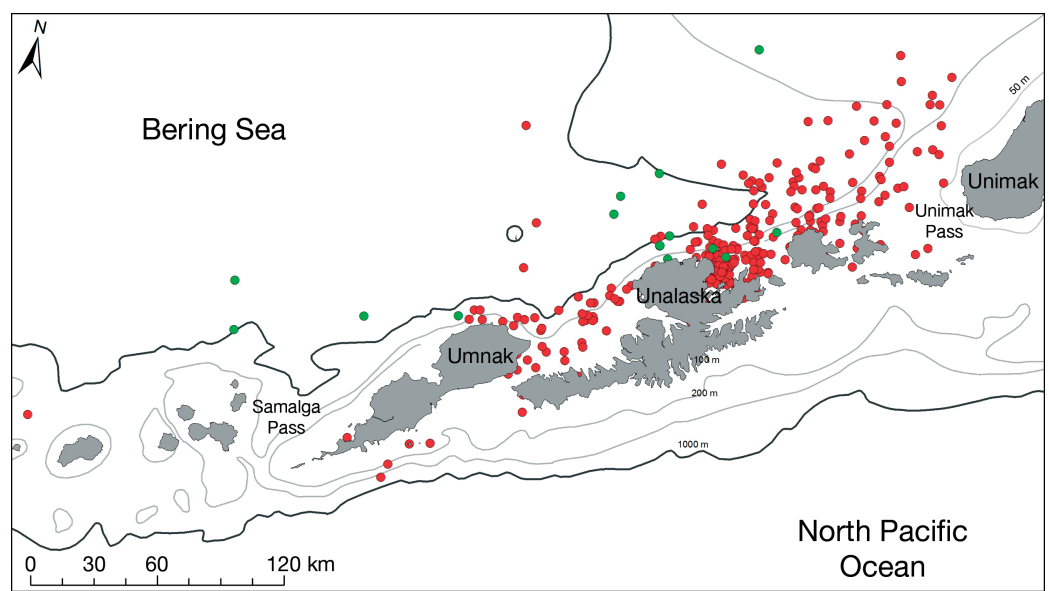

Fig. 3. Megaptera novaeangliae. Locations of foraging (red circles) and travel (green circles) modes for all tagged whales except Whale G (see Fig. 4). Unclassified behavior modes are not shown

suggests that whales are making individual decisions about fine-scale movement and that these decisions can lead to long-distance travel to remote, understudied habitats within a feeding season.

There is an abrupt division of water mass properties at Samalga Pass $(200 \mathrm{~km}$ west of Dutch Harbor): waters east of the pass are consistently warmer and fresher, with significantly higher primary productivity than those to the west (Ladd et al. 2005a,b, Mordy et al. 2005, Hunt et al. 2010). Correspondingly, the highest concentrations of humpback sightings along the Aleutian chain have consistently occurred from Samalga Pass east to Unimak Pass (Moore et al. 2000, Hunt \& Stabeno 2005, Zerbini et al. 2006a, Calambokidis et al. 2008, Friday et al. 2013), with very few humpbacks seen west of Samalga Pass. Telemetry data align with those findings; only 1 tagged animal traveled west of Samalga Pass for 3 d in 2007, but it looped back to the northern side of Unalaska Island without lingering in the pass itself (Figs. 2 \& 3). Additionally, Whales B, C and F spent several days (presumably foraging) just north of Umnak Island, as well as in Umnak Pass (Fig. 3). Previous surveys near Umnak Island have shown low humpback encounter rates (Zerbini et al. 2006a, Riley 2010), yet telemetry data from this study suggest that this area may be used more often than previously thought.

The majority of foraging behavior occurred over the shelf/slope habitat (1000 m or less) on the Bering Sea side of the Aleutian Island chain, rather than the bathymetrically similar North Pacific side (Fig. 3). This preference for the northern side of the Aleutian Islands has also been observed in previous visual sur- veys (Zerbini et al. 2006a, National Marine Mammal Laboratory unpubl. data), and is likely the result of the oceanographic processes that create consistent prey concentrations just west of Unimak Pass (Ladd et al. 2005a,b, Mordy et al. 2005). Although the Bering Sea shelf/slope area appears to be used more often, Mate et al. (2007) tracked 2 whales from Hawaii to the Pacific side of the Aleutian Islands; one of those tagged whales stayed on the shelf/ slope south of Umnak for $59 \mathrm{~d}$. Additionally, 2 whales from the present study (Whales $\mathrm{C}$ and F) also travelled through Umnak Pass to forage in the Pacific in different years (Fig. 3). Finescale oceanographic and biological productivity studies are needed to help describe conditions that warrant the use of this historically less-productive habitat.

Vessel surveys conducted throughout the Bering Sea in 2002, 2008 and 2010 recorded an increase in humpback sightings (as well as overall cetacean diversity and density) in 2010 in the Pervenets and Navarin canyons when compared with other survey years (Brueggeman et al. 1984, Friday et al. 2013). The increased cetacean sightings in this area in 2010 corresponded with the track of Whale G, who spent several days foraging in Navarin Canyon that same year (Fig. 4). Interestingly, the animal initially traveled through the canyon $11 \mathrm{~d}$ earlier without stopping to forage, but then looped back to forage there for $3 \mathrm{~d}$ before transmissions ceased (Fig. 4). The extent of use of these submarine canyons in the Bering Sea is unknown, but these data suggest that the canyons along the Bering Sea shelf break may represent important humpback whale foraging habitat.

Average daily distances traveled during this study were similar to those observed on other feeding grounds (Heide-Jørgensen \& Laidre 2007, Dalla Rosa et al. 2008), with the exception of Whale G, who traveled more than 2 times faster and farther than the average speed and distance of the 7 other tagged whales (Figs. $2 \& 4$ ). The speed and distance traveled by Whale $\mathrm{G}$ more closely resemble migratory travel rates than foraging rates (Mate et al. 1998, Zerbini et al. 2006b, Garrigue et al. 2010), yet the late-summer sighting (August) and the fact that Whale G was tagged while part of a large, surface-feeding group make it unlikely that this animal was still migrating so late in the season (August). Heide-Jørgensen \& Laidre (2007) recorded comparable speeds within a feeding 


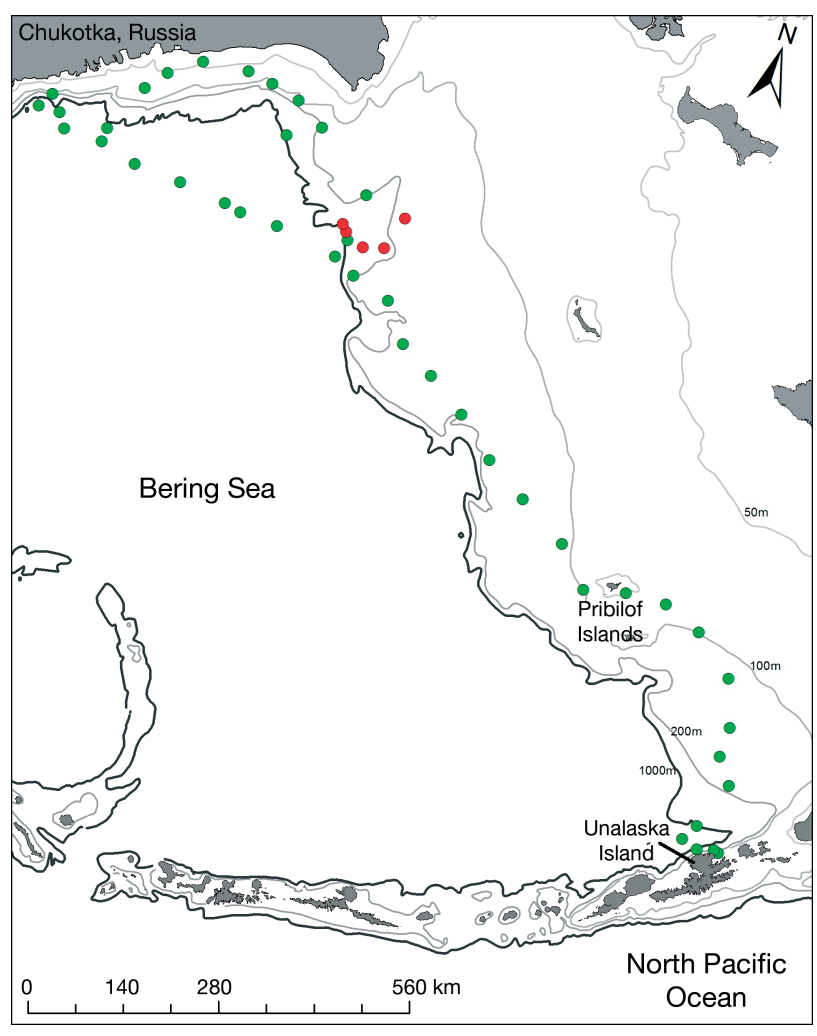

Fig. 4. Megaptera novaeangliae. Locations of foraging (red circles) and travel (green circles) modes for Whale G in 2010. Unclassified behavior modes are not shown

season when they tagged humpbacks off West Greenland and found that some moved up to $200 \mathrm{~km}$ per day, presumably in search of food. Additionally, Dalla Rosa et al. (2008) tracked a humpback that traveled a similar straight-line distance as Whale $\mathrm{G}$, averaging $\sim 108 \mathrm{~km} \mathrm{~d}^{-1}$ while traveling between presumed feeding sites off the Antarctic Peninsula.

Other long-distance travel events, across feeding aggregations, have been documented through photoidentification in the Gulf of Maine, yet $95 \%$ of those across-aggregation resightings occurred within $550 \mathrm{~km}$ of their original sighting location (Stevick et al. 2006). Similarly, in the North Pacific, less than $1 \%$ of all whales photographed on a feeding ground during the SPLASH project $(\mathrm{n}=4328)$ were re-sighted more than $740 \mathrm{~km}$ from their original sighting (Calambokidis et al. 2008). Furthermore, only 2 individually identified humpbacks (out of hundreds) seen in the Bering Sea and/or the Aleutian Islands were resighted elsewhere during $\mathrm{SPLASH}_{\text {; }}$ one was seen in southeastern Alaska, and one in the northern Gulf of Alaska (Calambokidis et al. 2008). Although humpbacks are commonly seen off the Chukotka Peninsula (Russia) (Tomilin 1937, Omura \& Ohsumi
1964), there have been no photo-identification matches between eastern Aleutian Island and Chukotka humpbacks, probably due to the near-total lack of this type of study effort in the latter area. However, Omura \& Ohsumi (1964) documented a humpback whale tagged with a Discovery mark near Unimak Pass that was recovered by a Japanese whaling vessel 8 yr later off Chukotka. The Omura \& Ohsumi (1964) record and the telemetry data from 2010 prove that at least some whales that feed along the eastern Bering Sea shelf and slope also visit the eastern coast of Russia. Long-distance movement variation like this has the potential to bias any population density estimate (Hammond et al. 1990, Friday 1997, Punt et al. 2007), and the scope of this phenomenon within the Bering Sea warrants further investigation.

The impact of anthropogenic injury or mortality on humpback whales throughout the Bering Sea is not well known, but fishing gear entanglements and ship strikes have been observed throughout Alaskan waters (Angliss \& Outlaw 2008, Neilson et al. 2012). Although Unalaska Bay has been a heavily trafficked fishing port for many years, human activity between the Aleutian Islands and the Chukchi Sea will likely increase as newly opened oil and gas lease areas in the Alaskan Arctic are developed. Telemetry data from this study highlight the overlap of humpback whale foraging habitat with areas of heavy shipping and fishing vessel traffic, such as Unalaska Bay and Unimak Pass, and management strategies should incorporate these results in order to strengthen their current conservation policies.

Acknowledgements. Funding was provided by the North Pacific Research Board (NPRB, project 720) and by the Bureau of Ocean Energy Management via an Interagency Agreement (OCS/BOEM study no. 2012-074) with the National Marine Mammal Laboratory (NMML), Alaska Fisheries Science Center (AFSC), National Oceanic and Atmospheric Administration (NOAA). Assistance with tag deployment was provided by Mikkel Jensen, Hans Christian Schmidt, Ygor Geyer, Billy Adams, Tony Martinez and Suzanne Yin. Assistance from the captain and crew of the ships used during the NMML North Pacific right whale cruises in the Bering Sea as well as the impressive effort of observers in finding whales is greatly appreciated. We are grateful for insightful reviews and suggestions for this manuscript from Dr. Jeremy Sterling, Dr. Marilyn Dahlheim and Heather Riley. Tag deployment, photo-identification and biopsy sampling were performed according to regulations and restrictions specified in existing permits issued by the National Marine Fisheries Service to the NMML (permit nos. 782-1719-03 and 14245). The findings and conclusions in the paper are those of the authors and do not necessarily represent the views of the National Marine Fisheries Service, NOAA. Reference to trade names does not imply endorsement by the National Marine Fisheries Service. 


\section{LITERATURE CITED}

Andrews RD, Pitman RL, Ballance LT (2008) Satellite tracking reveals distinct movement patterns for type B and type C killer whales in the southern Ross Sea, Antarctica. Polar Biol 31:1461-1468

Angliss RP, Outlaw RB (2008) Alaska marine mammal stock assessments, 2007. NOAA Tech Memo NMFS-AFSC180. US Department of Commerce, Seattle, WA

Argos (1990) User's manual. Service Argos, Landover, MD, USA

Baker CS (1985) The population structure and social organization of humpback whales (Megaptera novaeangliae) in the central and eastern North Pacific. PhD dissertation, University of Hawaii, Manoa, HI

- Baker CS, Perry A, Herman LM (1987) Reproductive histories of female humpback whales Megaptera novaeangliae in the North Pacific. Mar Ecol Prog Ser 41:103-114

Baker CS, Palumbi S, Lambertsen R, Weinrich M, and others (1990) Influence of seasonal migration on geographic distribution of mitochondrial DNA haplotypes in humpback whales. Nature 344:238-240

Baker CS, Medrano-Gonzales L, Calambokidis J, Perry A, and others (1998) Population structure of nuclear and mitochondrial DNA variation among humpback whales in the North Pacific. Mol Ecol 7:695-707

Barlow J, Calambokidis J, Falcone EA, Baker CS and others (2011) Humpback whale abundance in the North Pacific estimated by photographic capture-recapture with bias correction from simulation studies. Mar Mamm Sci 27(4): 793-818

Brueggeman JJ, Grotefendt R, Erickson AW (1984) Endangered whale abundance and distribution in the Navarin Basin of the Bering Sea during the ice-free period, Vol 84. Alaska Sea Grant College Program, University of Alaska

Byrd GV, Renner HM, Renner M (2005) Distribution patterns and population trends of breeding seabirds in the Aleutian Islands. Fish Oceanogr 14:139-159

Calambokidis J, Steiger GH, Evenson JR, Flynn KR and others (1996) Interchange and isolation of humpback whales off California and other North Pacific feeding grounds. Mar Mamm Sci 12:215-226

- Calambokidis J, Steiger GH, Straley JM, Herman LM, and others (2001) Movements and population structure of humpback whales in the North Pacific. Mar Mamm Sci 17:769-794

Calambokidis J, Falcone EA, Quinn TJ, Burdin AM and others (2008) SPLASH: structure of populations, levels of abundance and status of humpback whales in the North Pacific. Final report for contract AB133F-03-RP0078, Cascadia Research Collective, Olympia, WA

> Clapham PJ, Mead JG (1999) Megaptera novaeangliae. Mamm Species 604:1-9

> Clapham PJ, Baraff LS, Carlson CA, Christian MA and others (1993) Seasonal occurrence and annual return of humpback whales (Megaptera novaeangliae) in the southern Gulf of Maine. Can J Zool 71:440-443

Coyle KO (2005) Zooplankton distribution, abundance and biomass relative to water masses in eastern and central Aleutian Island passes. Fish Oceanogr 14(Suppl):77-92

> Dalla Rosa L, Secchi ER, Maia YG, Zerbini AN, HeideJørgensen MP (2008) Movements of satellite-monitored humpback whales on their feeding ground along the Antarctic Peninsula. Polar Biol 31:771-781

> Darling JD, McSweeney DJ (1985) Observations on the migrations of North Pacific humpback whales (Megaptera novaeangliae). Can J Zool 63:308-314
Dawbin WH (1966) The seasonal migratory cycle of humpback whales. In: Noris KS (ed) Whales, dolphins and porpoises. University of California Press, Berkeley, CA, p 145-171

Dolphin WF (1987) Foraging ecology and energetics of the humpback whale in southeast Alaska. PhD dissertation, Boston University, Boston, MA

Fleming A, Jackson J (2011) Global review of humpback whales (Megaptera novaeangliae). NOAA Tech Memo NMFSC-SWFSC-474. US Department of Commerce, La Jolla, CA

Freitas C (2010) argosfilter: Argos locations filter. R package version 0.62. http://CRAN.R-project.org/package=argos filter

Friday NA (1997) Evaluating photographic capture-recapture estimates of abundance of North Atlantic humpback whales. PhD dissertation, University of Rhode Island, Kingston, RI

Friday NA, Zerbini AN, Waite JM, Moore SE, Clapham PJ (2013) Cetacean distribution and abundance in relation to oceanographic domains on the Eastern Bering Sea shelf, June and July of 2002, 2008, and 2010. Deep-Sea Res II 94:244-256

Garrigue C, Zerbini AN, Geyer Y, Heide-Jørgensen MP, and others (2010) Movements of satellite-monitored humpback whales from New Caledonia. J Mammal 91: 109-115

Hammond PS, Mizroch SA, Donovan GP (eds) (1990) Individual recognition of cetaceans: use of photo-identification and other techniques to estimate population parameters. Spec Issue 12, International Whaling Commission, Cambridge

Heide-Jørgensen MP, Laidre KL (2007) Autumn space-use patterns of humpback whales (Megaptera novaeangliae) in West Greenland. J Cetacean Res Manag 9:121-126

> Heide-Jørgensen MP, Kleivane L, Oien N, Laidre KL, Jensen MV (2001) A new technique for deploying satellite transmitters on baleen whales: tracking a blue whale (Balaenoptera musculus) in the North Atlantic. Mar Mamm Sci 17:949-954

Heide-Jørgensen $M$, Laidre $K$, Wiig $\varnothing$, Jensen $M$, and others (2003) From Greenland to Canada in ten days: tracks of bowhead whales, Balaena mysticetus, across Baffin Bay. Arctic 56:21-31

$>$ Heide-Jørgensen MP, Laidre KL, Jensen MV, Dueck L, Postma LD (2006) Dissolving stock discreteness with satellite tracking: bowhead whales in Baffin Bay. Mar Mamm Sci 22:34-45

> Horton TW, Holdaway RN, Zerbini AN, Hauser ND and others (2011) Straight as an arrow: humpback whales swim constant course tracks during long-distance migration. Biol Lett 7:674-679

> Hunt GL Jr, Stabeno PJ (2005) Oceanography and ecology of the Aleutian Archipelago: spatial and temporal variation. Fish Oceanogr 14:292-306

Hunt GL Jr, Allen BM, Angliss RP, Baker T and others (2010) Status and trends of the Bering Sea region, 2003-2008. In: McKinnell SM, Dagg MJ (eds) Marine ecosystems of the North Pacific Ocean 2003-2008. North Pacific Marine Science Organization (PICES), Vancouver, p 196-267

> Jonsen ID, Flemming JM, Myers RA (2005) Robust statespace modeling of animal movement data. Ecology 86: 2874-2880

Jonsen ID, Myers RA, James MC (2007) Identifying leatherback turtle foraging behaviour from satellite telemetry using a switching state-space model. Mar Ecol Prog Ser $337: 255-264$ 
Kareiva P, Odell G (1987) Swarms of predators exhibit 'preytaxis' if individual predators use area-restricted search. Am Nat 130:233-270

Katona SK, Beard JA (eds) (1990) Population size, migrations and feeding aggregations of the humpback whale (Megaptera novaeangliae) in the western North Atlantic Ocean. In: Hammond PS, Mizroch SA, Donovan GP (eds) Individual recognition of cetaceans: use of photo-identification and other techniques to estimate population parameters. International Whaling Commission, Cambridge, Spec Issue 12, p 295-305

Krieger K, Wing B (1984) Humpback whale prey studies in southeastern Alaska, summer 1983. Northwest and Alaska Fisheries Science Centers, Auke Bay Laboratory, Auke Bay, AK

Ladd C, Hunt GL Jr, Mordy CW, Salo SA, Stabeno PJ (2005a) Marine environment of the eastern and central Aleutian Islands. Fish Oceanogr 14:22-38

Ladd C, Jahncke J, Hunt GL Jr, Coyle KO, Stabeno PJ (2005b) Hydrographic features and seabird foraging in Aleutian passes. Fish Oceanogr 14:178-195

Lunn DJ, Thomas A, Best N, Spiegelhalter D (2000) Winbugs - a Bayesian modelling framework: concepts, structure, and extensibility. Stat Comput 10:325-337

> Mate BR, Gisiner R, Mobley J (1998) Local and migratory movements of Hawaiian humpback whales tracked by satellite telemetry. Can J Zool 76:863-868

Mate BR, Mesecar R, Lagerquist B (2007) The evolution of satellite-monitored radio tags for large whales: one laboratory's experience. Bio-logging science: logging and relaying physical and biological data using animalattached tags. Proceedings of the 2005 International Symposium on Bio-logging Science, Second International Conference on Bio-logging Science. Deep-Sea Res Part II 54:224-247

> Mayo CA, Marx MK (1990) Surface foraging behavior of the north atlantic right whale, Eubalaena glacialis, and associated zooplankton characteristics. Can J Zool 68: 2214-2220

Mehta AV, Allen JM, Constantine R, Garrigue C and others (2007) Baleen whales are not important as prey for killer whales Orcinus orca in high-latitude regions. Mar Ecol Prog Ser 348:297-307

Moore SE, Waite JM, Mazzuca LL, Hobbs RC (2000) Mysticete whale abundance and observations of prey associations on the central Bering Sea shelf. J Cetacean Res Manag 2:227-234

Moore SE, Waite JM, Friday NA, Honkalehto T (2002) Cetacean distribution and relative abundance on the central-eastern and the southeastern Bering Sea shelf with reference to oceanographic domains. Prog Oceanogr 55:249-261

Mordy CW, Stabeno PJ, Ladd C, Zeeman S, and others (2005) Nutrients and primary production along the eastern Aleutian Island Archipelago. Fish Oceanogr 14: $55-76$

Neilson JL, Gabriele CM, Jensen AS, Jackson K, Straley JM (2012) Summary of reported whale-vessel collisions in Alaskan waters. J Mar Biol 2012:106282

Nemoto T (1957) Foods of baleen whales in the northern Pacific. Sci Rep Whales Res Inst Tokyo 12:33-89

Nemoto T (1962) Distribution of five main euphausiids in the Bering and the northern part of the North Pacific. J Oceanogr Soc Jpn 27:615-627

Omura H, Ohsumi S (1964) A review of Japanese whale marking in the North Pacific to the end of 1962, with some information on marking in the Antarctic. Norsk Hvalfangst-tidende 53:90-112

Perry A, Baker CS, Herman LM (1990) Population characteristics of individually identified humpback whales in the central and eastern North Pacific: a summary and critique. Rep Int Whal Comm 12:307-317

Punt AE, Friday NA, Smith TD (2007) Reconciling data on the trends and abundance of North Atlantic humpback whales within a population modelling framework. J Cetacean Res Manag 8:145-159

R Development Core Team (2011) R: A language and environment for statistical computing. R Foundation for Statistical Computing, Vienna. www.R-project.org/

> Reed R, Stabeno P (1994) Flow along and across the Aleutian Ridge. J Mar Res 52:639-648

Riley HE (2010) Humpback whale (Megaptera novaeangliae) numbers and distribution on their summer feeding grounds of the eastern Aleutian Islands. MSc thesis, University of Alaska, Fairbanks

Royer TC, Hansen DV, Pashinski DJ (1979) Coastal flow in the northern Gulf of Alaska as observed by dynamic topography and satellite-tracked drogued drift buoys. J Phys Oceanogr 9:785-801

Schorr GS, Baird RW, Hanson MB, Webster DL and others (2009) Movements of satellite-tagged Blainville's beaked whales off the island of Hawai'i. Endang Species Res 10: 203-213

Sinclair EH, Moore SE, Friday NA, Zeppelin TK, Waite JM (2005) Do patterns of steller sea lion (Eumetopias jubatus) diet, population trend and cetacean occurrence reflect oceanographic domains from the Alaska Peninsula to the central Aleutian Islands? Fish Oceanogr 14: 223-242

Spiegelhalter D, Thomas A, Best N, Lunn D (2003) Winbugs user manual. Medical Research Council (MRC) Biostatistics Unit, Cambridge

Stevick PT, Allen J, Clapham PJ, Datona SK, and others (2006) Population spatial structuring on the feeding grounds in North Atlantic humpback whales (Megaptera novaeangliae). J Zool 270:244-255

Tomilin AG (1937) Whales of the Russian Far East. Proc Moscow State Univ 23:119-167

Waite J, Dahlheim M, Hobbs R, Mizroch S (1999) Evidence of a feeding aggregation of humpback whales (Megaptera novaeangliae) Around Kodiak Island, Alaska. Mar Mamm Sci 15:210-220

Witteveen BH, Worthy GAJ, Wynne KM, Roth JD (2009) Population structure of North Pacific humpback whales on their feeding grounds revealed by stable carbon and nitrogen isotope ratios. Mar Ecol Prog Ser 379:299-310

Zerbini AN, Waite JM, Laake JL, Wade PR (2006a) Abundance, trends and distribution of baleen whales off western Alaska and the central Aleutian Islands. Deep-Sea Res I 53:1772-1790

Zerbini AN, Andriolo A, Heide-Jørgensen MP, Pizzorno JL and others (2006b) Satellite-monitored movements of humpback whales Megaptera novaeangliae in the Southwest Atlantic Ocean. Mar Ecol Prog Ser 313: 295-304

Zerbini AN, Andriolo A, Heide-Jørgensen MP, Moreira S and others (2011) Migration and summer destinations of humpback whales (Megaptera novaeangliae) in the western South Atlantic Ocean. J Cetacean Res Manag 3: $113-118$

Submitted: May 28, 2013; Accepted: November 16, 2013

Proofs received from author(s): February 24, 2014 